\title{
Kondisi Kehidupan Wanita Single Parent
}

\author{
Succy Primayuni \\ Universitas Negeri Padang \\ *) Correspondence regarding this article should be addressed to: Author address e-mail: \\ succyprimayuni@gmail.com
}

\begin{abstract}
Masalah yang akan dikaji dalam hal ini, yaitu bagaimana kondisi kehidupan wanita single parent sebelum menjadi single parent? Sebelum membahas masalah tersebut maka akan dijelaskan terlebih dahulu apa itu single parent. Single parent adalah seseorang yang mengalami kehilangan pasangan disebabkan karena, perceraian dan ditinggal mati oleh pasangan. Sager, ada 2 macam bentuk single parent yaitu 1) Single Parent Mother yaitu ibu sebagai seorang orangtua tunggal harus menggantikan peran ayah sebagai kepala keluarga, pengambil keputusan, pencari nafkah disamping perannya sebagai mengurus rumah tangga, membesarkan, membimbing dan memenuhi kebutuhan psikis remaja. 2) Single Parent Father yaitu ayah sebagai orangtua tunggal harus menggantikan peran ibu sebagai pengurus rumah tangga yang mengerjakan pekerjaan rumah tangga, di samping perannya sebagai kepala rumah tangga
\end{abstract}

Keywords: Single Parent, kondisi single parent

Article History: Received on 10/03/2019; Revised on 13/04/2019; Accepted on 20/04/2019; Published Online: 30/04/2019.

This is an open access article distributed under the Creative Commons Attribution License, which permits unrestricted use,
distribution, and reproduction in any medium, provided the original work is properly cited. (C)2019 by author.

Semua wanita idealnya tak ada yang mau menjadi single parent. Karena hal itu bukanlah pilihan melainkan satu kondisi yang tidak mudah dihadapi. Namun, pada akhirnya status itu bisa menimpa siapa saja. Entah itu ibu rumah tangga biasa atau wanita karier yang sedang berada di posisi puncak. Status itu bisa terjadi akibat pasangan meninggal dunia, sayap pun terkepak tinggal sebelah, sedangkan kehidupan terus berjalan. Bila seorang ibu tidak kuat dan kokoh maka anak-anaknya akan menderita dan terpuruk. Siap atau tidak siap, menjadi single mother harus dijalani untuk bisa melanjutkan kehidupan ini.

Single parent adalah gambaran seorang perempuan tangguh. Segala hal berkenaan rumah tangga ditanggung sendiri. Mulai membereskan rumah, mencari nafkah keluarga, dilakoni sendiri. Dalam posisi ini, seorang wanita diharuskan untuk bisa berperan ganda, menjadi ibu sekaligus ayah bagi anakanaknya. Tugas pun semakin besar, yang mengasuh, membesarkan, dan mendidik anak-anak, juga ia harus menjadi tulang punggung keluarga dalam mencari nafkah. Semua ini bukanlah hal yang mudah. Apalagi 


\section{Kondisi Kehidupan Wanita Single Parent}

jika dialami kaum perempuan yang manja, kurang tangguh, dan sangat bergantung pada orang lain. Terlebih ketika sebelumnya ia sama sekali tidak terbiasa menjalani kehidupan berat, karena selama ini sudah terpenuhi suaminya ketika masih bersama.

Pertumbuhan keluarga yang berorang tua tunggal saat ini merupakan fenomena yang berlangsung terus. Di Dusun Sekarwoyo Desa Sukomulyo Kecamatan Manyar Kabupaten Gresik terjadinya single parent perempuan dikarenakan kematian salah satu pasangan hidup. Perjuangan hidup single parent sangatlah berarti bagi keluarganya. Di mana ibu yang harus berjuang untuk menghidupi keluarga, baik kebutuhan sehari-hari maupun biaya sekolah anaknya. Itupun dilakukan tanpa rasa lelah dan mengeluh. Karena seorang ibu yang menjadi single parent tidak ingin melihat anak-anaknya terlantar dan menjadi putus asa karena tidak memiliki seorang ayah.

Wanita single parent harus pandai membagi waktu, melengkapi statusnya sebagai ayah dan ibu sekaligus. Perannya sebagai ayah, sebagai pemimpin keluarga kecil yang dimilikinya. Kemandirian dalam mengambil keputusan dan membuat kebijakan secara mandiri untuk keluarga kecilnya. Selain itu harus menafkahi kebutuhan hidup dalam keluarganya.

Perannya sebagai ibu, yaitu menjalankan kodratnya sebagai perempuan, meliputi mengasuh dan membesarkan anaknya, serta hal-hal yang ada dalam rumah. Walaupun dalam kondisi bekerja, tetap harus memonitor apa yang terjadi di dalam rumah. Mempersiapkan kemandirian untuk mental si anak juga sangat perlu. Kasih sayang adalah kunci segala-galanya. Memberi pengertian kepada anak pelan-pelan dengan menyesuaikan usianya. Tidak bisa dihindari, anak akan mengalami dampak psikologis yang akan mempengaruhi terhadap perilakunya di rumah, sekolah, dan masyarakat. Menumbuhkan kepercayaan dirinya dan meningkatkan rasa nyaman merupakan tugas utama. Anak merupakan skala prioritas, karena tanpa itu semua karir dan peran yang dijalani akan sia-sia.

\section{PEMBAHASAN}

\section{Keluarga}

Keluarga merupakan unit sosial terkecil yang bersifat universal, artinya keluarga terdapat pada setiap masyarakat di dunia. Dalam pengertian psikologis, keluarga adalah beberapa orang yang bertempat tinggal di tempat yang sama dan juga hidup bersama yang didalamnya setiap anggotanya dapat merasakan adanya kasih sayang yang juga memperhatikan, memperdulikan dan mempengaruhi satu sama lain. Kemudian dalam pedagogis yang dimaksud dengan keluarga adalah "satu" perkumpulan yang didasari dengan kasih sayang diantara dua gender yaitu laki-laki dan perempuan yang disatukan melalui ikatan pernikahan bertujuan agar saling mengasihi dan melengkapi satu sama lain hal tersebut mengandung tujuan untuk mewujudkan tugas dan posisi nantinya sebagai orangtua (Shochib, 1998).

Terdapat beragam istilah yang bisa dipergunakan untuk menyebut "keluarga". Keluarga adalah "suatu kelompok yang terdiri dari dua atau lebih yang direkat oleh ikatan darah, perkawnan, atau adopsi seta tinggal bersama" (Suhendi, 2001). Keluarga 
adalah "ikatan persekutuan hidup atas dasar perkawinan antara seorang suami dan istri yang bersama untuk mencapai hidup yang kekal dan abadi dengan rasa cinta, kasih dan sayang berdasarkan ke Tuhanan Yang Maha Esa" (Hasan, 2006).

\section{Keluarga Utuh}

Keluarga yang disebut utuh merupakan keluarga yang lengkap strukturnya, yaitu yang terdiri dari ayah, ibu dan anak yang tinggal di dalam sebuah rumah tangga dan saling berinteraksi satu sama lainnya serta menjalankan peran sebagaimana anggota keluarga dalam masyarakat. Keluarga yang ideal (fungsional normal) yang ditandai oleh ciri-ciri (S. Yusuf, 2004): (a) Minimnya perselisihan antar orangtua dan anaknya, (b) Memiliki kesempatan untuk mengatakan keinginan, (c) Didasari dan dipenuhi oleh kasih sayang, (d) Tidak terlalu mengekang anak untuk mewujudkan disiplin yang keras, (e) Berkesempatan untuk bersikap mandiri, (f) Saling menghormati dan juga menghargai sesama anggota keluarga, (g) Terdapat kerjasama untuk menyelesaikan masalah dari semua anggota keluarga, (h) Mewujudkan kebersamaan dan kekompakan antara orangtua beserta anak, (i) Orangtua tidak terlalu emosional, (j) Dikategorikan cukup dalam hal ekonomi, (k) Patuh terhadap nilai-nilai agama.

Keluarga yang fungsional (normal) yaitu keluarga yang memahami dan melaksanakan tugasnya masing-masing (Dahlan, 2002). Keluarga yang normal memiliki karakteristik sebagai berikut: (a) Perhatian terhadap satu sama lain dan saling mencintai, (b)Tidak menutupi sesuatu atau jujur ketika berbicara, saling mendengarkan dan menghargai serta menerima satu sama lain, (c) Berbagi pendapat sesama anggota keluarga, (d) Mampu berjuang mengatasi masalah hidupnya, (e) Dapat menyesuaikan diri dan memenuhi kebutuhan, (f) Memberikan perlindungan dan kasih sayang sesama, (g) Memiliki komunikasi yang baik, (h) Keluarga dapat melengkapi kebutuhan anak dan menwariskan atau menanamkan nilai-nilai budaya, (i) Mampu beradaptasi dengan perubahan yang terjadi.

\section{Keluarga Broken Home}

Broken home merupakan suatu istilah yang biasa digunakan untuk menggambarkan keadaan keluarga yang bercerai-berai akibat dari orangtua yang sudah tidak lagi memperdulikan situasi, kondisi dan juga keadaan keluarganya. Orangtua yang tidak memberikan perhatianny terhadap anak-anak dalam berbagai persoalan yang dihadapinya. Tak sedikit dari orangtua tersebut yang memutuskan untuk bercerai karena memilih pekerjaan daripada keluarga. Keadaan broken home seperti ini membuktikan bahwa anggota keluarga tidak melaksanakan kewajibannya dan fungsinya sebagai anggota keluarga secara optimal. Broken home diartikan sebagai pecahnya suatu unit keluarga, terputusnya, retaknya struktur peran sosial jika satu atau beberapa anggota keluarga gagal menjalankan kewajiban peran mereka dengan baik (Lailahanoum, 2005).

Tidak sedikit pertikaian itu berujung perceraian karena orangtua tetap mempertahankan pendapatnya masing-masing tanpa mempedulikan nasib anak mereka nantinya. Penyebab terjadi perceraian adalah (Ichsan, 2009): (a) orangtua kurang dewasa, (b) ketidak harmonisan rumah tangga, (c) pihak ketiga, (d) kurangnya pendidikan kekeluargaan, (e) kebiasaan buruk orangtua, (f) faktor ekonomi, (g) tidak mendapat keturunan. Selanjutnya (Willis, 2015) mengemukakan penyebab broken home adalah; (a) 


\section{Kondisi Kehidupan Wanita Single Parent}

ketidak berfungsian sistem keluarga, (b) keluarga materialistik, (c) istri berkuasa, dan (d) ketidak harmonisan hubungan seksual.

Dampak negatif dari broken home yang benar-benar sudah tidak bisa dihindari lagi yaitu memiliki pengaruh negatis bagi remaja baik dalam pertumbuhannya maupun dalam menyelesaikan tugas-tugas perkembangannya karena pada masa remaja merupakan masa-masa krisis identitas yang membuat remaja harus dalam perlakuan dan keadaan yang baik untuk menemukan identitasnya (Somantri, 2012). Keadaan keluarga yang kacau dapat membuat anak melakukan banyak hal negatif, memberikan contoh yang kurang baik sebagai acuan hidup seorang anak. Keadaan seperti itu juga membuat anak merasa tertekan disegi mental yang amat berat. Keluarga merupakan pondasi utama didalam hidup seseorang, seorang anak juga akan merasa malu pada lingkungan sekitar sehingga membuat ia menjauh dan mengucilkan diri dari teman-teman dan lingkungan karena khawatir akan mendapat respon yang tidak baik dan juga dapat mengganggu konsentrasinya dalam belajar (Somantri, 2012).

Broken home memiliki banyak efek negatif terhadap hidup seseorang, diantaranya adalah (Somantri, 2012):

1. Masalah akademik, anak akan menjadi malas belajar dan kehilangan semangat dalam mengejar prestasi.

2. Masalah tingkah laku, anak akan menjadi pemberontak, berbicara dan berperilaku kasar, tidak peduli dengan lingkungan dan mulai melakukan kebiasaan buruk dan juga pergaulan yang salah.

3. Masalah seks, karena ia merasa kurang mendapatkan kasih sayang dan melampiaskan terhadap hawa nafsu atau seks bebas.

4. Masalah agama, kehilangan sosok yang bisa membimbing dan mengarahkan ke jalan yang benar membuat anak merasa sesuatu yang berkaitan dengan agama hanya kemunafikan saja.

Dengan demikian terlihatlah bahwa broken home yang disebabkan perceraian orangtua sangat berdampak negatif kepada diri anak. Mereka akan merasa frustasi dengan keadaan orangtua mereka yang tidak lagi tinggal bersama. Secara akademis mereka juga tertinggal dari teman-teman yang lain karena tidak memiliki gairah dalam belajar karena terdapat masalah untuk mencapai kesuksesan belajarnya.

Single Parent

Pendidikan dalam keluarga memang memiliki nilai strategis dalam pembentukan kepribadian remaja. Sejak kecil remaja sudah memperoleh pendidikan dari kedua orangtuanya melalui keteladanan dan kebiasaan hidup sehari-hari dalam keluarga (Syaiful, 2004 : 25). Itu artinya, kedua orangtua memiliki peran dan tugas serta bertanggung jawab masing-masing dalam mendidik remaja. Diperkuat oleh M. Shochib (2010 : 18) yang mengatakan bahwa "keutuhan orangtua (ayah dan ibu) dalam sebuah keluarga sangat dibutuhkan dalam membantu remaja untuk memiliki dan mengembangkan dasar-dasar disiplin diri." 
Menurut Hurlock (1980 : 359-360) single parent adalah seseorang yang mengalami kehilangan pasangan udisebabkan karena, perceraian dan ditinggal mati oleh pasangan. Sager, dkk (dalam Budi, 2011 : 12) menambahkan bahwa single parent adalah orangtua yang secara sendirian membesarkan remaja-remajanya tanpa kehadiran, dukungan atau tanggungjawab dari pasangannya.

Newman, dkk (dalam Veronika, 2007 : 15) menyebutkan keluarga single parent adalah keluarga yang di dalam struktur keluarganya hanya terdapat satu orangtua saja baik ayah atau ibu yang disebabkan oleh kematian, perceraian, perkawinan tidak jelas dan pengadopsian remaja. Sementara itu, Haffman (dalam Veronika, 2007 : 15) juga mengartikan single parent sebagai orangtua yang merangkap ayah sekaligus ibu dalam membesarkan dan mendidik remajanya serta mengatur kehidupan keluarga karena perubahan struktur keluarga.

Kemudian, V. Dwiyani (2009 : 15) mendefinisikan orangtua tunggal sebagai orang yang mengasuh remaja sendirian, karena sudah tidak memiliki pasangan seperti bercerai, meninggal, tidak menikah atau yang masih memiliki pasangan tetapi terpisah oleh jarak karena berbagai sebab seperti bekerja atau belajar.

Santrock (1995 : 243) mengemukakan ada 2 macam bentuk single parent yaitu sebagai berikut:

1. Single Parent Mother yaitu ibu sebagai seorang orangtua tunggal harus menggantikan peran ayah sebagai kepala keluarga, pengambil keputusan, pencari nafkah disamping perannya sebagai mengurus rumah tangga, membesarkan, membimbing dan memenuhi kebutuhan psikis remaja.

2. Single Parent Father yaitu ayah sebagai orangtua tunggal harus menggantikan peran ibu sebagai pengurus rumah tangga yang mengerjakan pekerjaan rumah tangga, di samping perannya sebagai kepala rumah tangga.

Menurut Rahayu (dalam Penelitian Strategi Adaptasi Menjadi Single Mother 2013), Strategi adaptasi ekonomi dalam keluarga single mother nampak bagaimana mereka menyelaraskan antara jumlah pendapatan dengan kebutuhan setiap harinya. Single mother ditunut untuk untuk mampu menjalankan perannya sendiri tanpa pasangan hidup dengan cara bekerja di sektor publik dan menjadi pencari nafkah utama bagi anak dengan orang tuanya karena dengan hal inilah mereka dapat bertahan hidup bersama keluarga dan anak-anaknya. Misalnya pendidikan dan kebutuhan makan seharihari menuntut single mother untuk tidak kenal lelah mencari uang. Bentuk perencanaan berencanaan ekonomi juga terlihat dari cara single mother menabung, menyisihkan sebagaian pendapatannya sedikit demi sedikit yang bisa digunakan untuk memenuhi kehidupan pendidikan anaknya dan bisa juga digunakan untuk kebutuhan yang mendesak.

Single parent dalam sebuah keluarga tidaklah mudah terlebih pada seorang ibu yang harus mengasuh anaknya seorang diri karena kehilangan suami akibat percerain atau meninggal dunia. Hal tersebut membutuhkan perjuangan berat untuk membesarkan anak, termasuk memenuhi kebutuhan hidup keluarga baik pada saat yang bersamaan ia berperan ganda dalam keluarga sebagai ibu sekaligus sebagai ayah. Ibu di tuntut harus 


\section{Kondisi Kehidupan Wanita Single Parent}

meluangkan waktunya dan membagi waktunya untuk mencari nafkah dan memberikan kasih sayang kepada anaknya dan mereka akan selalu dihadapkan oleh berbagai masalah internal maupun masalah eksternal yang akan mempengaruhi kehidupan rumah tangga, Papalia (Rahma 2015:425). Masalah eksternal lebih sering datang dari masyarakat atau lingkungan tempat orangtua tunggal (single parent) tinggal.

Masyarakat akan memiliki pandangan yang berbeda-beda tentang single parent. Sedangkan masalah internal single parent berasal dari lingkungan keluarga dan anakanaknya. Single parent harus dapat memberikan pengertian, lebih sabar, dan tegar dalam menghadapi masalah dalam keluarganya. Single parent biasanya lebih merasa tertekan daripada orangtua utuh dalam kekompetenan sebagai orangtua. Kekompeten orangtua ini nantinya dapat berpengaruh pada bagaimana orangtua mengasuh anaknya. Menjadi ibu idaman tidak datang dengan sendirinya, semua itu dibentuk dari suatu proses pendewasaan dan perbaikan karakter, Papalia (Rahma 2015: 426). Kemandirian dalam jiwa ibu single parent sangat dibutuhkan untuk menjalankan peran ganda di sektor domestik, yaitu bertugas dalam urusan rumah tangga seperti memasak, mencuci piring dan pakaian, membersihkan rumah, menyiapkan makanan untuk keluarga, merawat, membesarkan dan mendidik anak-anaknya dan di sektor publik yaitu bertugas secara ekonomi agar kebutuhan tetap terpenuhi yaitu dengan mencari nafkah bagi keluarganya dan secara sosial yaitu bersosialisasi dengan masyarakat. Keseimbangan peran domestik dan publik perlu dicapai dengan usaha ekstra melalui proses kesabaran, ilmu, dan konsistensi untuk menjalankannya.

Sebagai seorang single parent untuk bekerja mencari nafkah tentunya banyak yang harus dipertimbangkan mulai dari sumber penghasilan yang relatif, waktu yang efisien agar tetap menjalankan tugas utama sebagai seorang ibu tunggal tanpa mengesampingkan tugas-tugas rumah tangga. Perempuan single parent dituntut untuk bisa beradaptasi dan melanjutkan hidup tanpa seorang suami, mencari nafkah dan menyeimbangkan antara peran domestik dan publik. Masing-masing diantaranya memiliki cara dan strategi sendiri dalam menjalani hidup sebagai single parent, karena keberhasilan seorang perempuan single parent dalam mendidik dan menafkahi anak tergantung pada bagaimana ia menerapkan cara untuk bisa menyeimbangkan waktu antara mencari nafkah dan mendidik anaknya, serta tak kalah penting adalah menjalin hubungan dengan masyarakat, bagaimana seorang single parent harus bersikap dan bertindak agar tidak di cemooh dan dianggap tabu oleh masyarakat. Jika melihat fenomena yang ada, berbagai masalah terkait dengan penjelasan diatas yang terjadi di Kelurahan Mungkajang Kecamatan Mungkajang Kota Palopo yaitu masalah dalam keluarga diantaranya suami-istri dalam hal ini Ayah dan Ibu. Hal ini dilatar belakangi oleh banyak faktor dan secara umum yang penulis temukan yaitu : 1. Perceraian antara suami-istri yang disebabkan oleh ketidak cocokan diantara mereka sehingga harus berpisah 2. Kematian salah satu pasangan sehingga pihak yang ditinggalkan menjadi single parent bagi anak-anaknya.

\section{KESIMPULAN}

Berdasarkan pada pembahasan di atas, maka dapat disimpulkan bahwa kondisi kehidupan single parent sangat tidak mudah, single parent banyak mengalami tekanan- 
tekanan dalam mengatur keuangan keluarga, sulit dalam bidang kehidupan karir. Wanita single parent juga harus pandai membagi waktu antara pekerjaan dan waktu untuk anakanaknya. Karena wanita single parent memiliki dua peran yaitu sebagai ibu dan juga ayah. Penyebab seseorang menjadi single parent yaitu karena bercerai hidup mengalami masalah yang paling banyak adalah pada kehidupan berkeluarga yaitu pada aspek hubungan dengan keluarga besar pihak suami. Sedangkan pada single parent cerai mati mengalami masalah terbanyak pada kehidupan pribadi yaitu aspek kondisi jasmani dan kesehatan.

\section{REFERENCES}

Shochib, M. (1998). Pola Asuh Orangtua. Jakarta: Rineka Cipta.

Suhendi, H. (2001). Pengantar Studi Sosiologi Keluarga. Bandung: Pustaka Setia.

Hasan, M. (2006). Bahan Ajar Bimbingan Konseling Keluarga. Padang: FIP UNP.

Dahlan, M. D. (2002). Psikologi Perkembangan Anak dan Remaja. Bandung: Remaja Rosdakarya.

Lailahanoum. (2005). The Family (William J. Goode. Terjemahan). Jakarta: Bumi Aksara.

Ichsan, M. (2009). Jangan Pernah Bercerai. Yogyakarta: Ichsani Media.

Willis, S. S. (2015). Konseling Keluarga. Bandung: Alfabeta.

Somantri, A. (2012). Pengertian dan Dampak Broken Home.

http://sumformasi19.blogspot.com/2012/10/pengertian-broken-home-dan-dampak.html

Diakses pada tanggal 19 Desember 2018. (dalam Skripsi Sharfina Rahmi, 2014). 